\title{
Ethical questions of digitalization in the Global South
}

\author{
Perspectives on justice and equality
}

\begin{abstract}
Kerstin Schopp, International Center for Ethics in the Sciences and Humanties, University of Tübingen, Wilhelmstraße 19, 72074 Tübingen (kerstin.schopp@uni-tuebingen.de) Laura Schelenz, International Center for Ethics in the Sciences and Humanties, University of Tübingen (laura.schelenz@uni-tuebingen.de) Jessica Heesen, International Center for Ethics in the Sciences and Humanties, University of Tübingen (jessica.heesen@uni-tuebingen.de) Maria Pawelec, International Center for Ethics in the Sciences and Humanties, University of Tübingen (maria.pawelec@uni-tuebingen.de)
\end{abstract}

Digitalization and information and communications technology (ICT) influence and transform the world economy, our everyday life, politics, and our way of communicating. This entails opportunities and benefits as well as risks, challenges, and difficulties for all actors involved. Especially in the African context, but also in other countries of the Global South, there are important questions and aspects of digitalization which have to be addressed by technology assessment (TA) from an ethical point of view: questions of unequal power relations, neo-colonialism, (digital) illiteracy and language barriers, general barriers to access, and the gender digital divide. To broaden the perspectives of TA in global contexts, these issues should be discussed by different scientific disciplines, equally considering the positions of those affected. The inter- and transdisciplinary approaches in this TATuP special topic make a much-needed contribution to TA of digitalization in a global context.

\section{Ethische Fragen zur Digitalisierung im Globalen Süden}

Perspektiven auf Gerechtigkeit und Gleichberechtigung

Digitalisierung und Informations- und Kommunikationstechnologien (IKT) beeinflussen und verändern die Weltwirtschaft, unser Alltagsleben, die Politik und unsere Kommunikation. Das birgt Chancen und Vorteile, aber auch Risiken, Herausforderungen und Schwierigkeiten für alle beteiligten Akteur*innen. Besonders im afrikanischen Kontext, aber auch in anderen Ländern des Globalen Südens, gibt es wichtige Fragen und Aspekte der Digitalisierung, die in der Technikfolgenabschätzung (TA) von einem ethischen Standpunkt aus adressiert werden müssen: Fragen zu ungleichen Machtverhältnissen, Neokolonialismus, (digitalem) Analphabetismus und sprachlichen Barrieren sowie zu allgemeinen Zugangsbarrieren und der digitalen Kluft zwischen den Geschlechtern. Um die Perspektive von TA in globalen Kontexten zu erweitern, sollten diese Fragen aus unterschiedlichen wissenschaftlichen Disziplinen heraus diskutiert und die Perspektive derjenigen miteinbezogen werden, die im konkreten Fall betroffen sind. Die inter- und transdiszipli-

This is an article distributed under the terms of the Creative Commons Attribution License CCBY 4.0 (https://creativecommons.org/licenses/by/4.0/)

https://doi.org/10.14512/tatup.28.2.s11 nären Ansätze in diesem TATUP-Thema leisten einen wichtigen Beitrag zur TA der Digitalisierung im globalen Kontext.

Keywords: digitalization, ICT access barriers, power relations, ethical questions, value-laden technology

\section{Introduction}

Although people in the Global North are usually not exposed to the latest developments in the Global South, it seems that Northern media increasingly reports stories of digitalization processes in the Global South, especially in Africa: Africa as an untapped pool of digital talent, Africa leapfrogging development and closing the digital divide, Africa as a home to start-ups and international tech hubs. Transnational corporations deliver a growing number of services to the continent. On the one hand, the governments of China, Europe, and the United States of America (USA), development organizations, civil society, and researchers also increasingly promote, implement or analyze digitalization in the Global South, particularly in Africa. On the other hand, governments of countries in the Global South are themselves striving for digitalization at home.

The worldwide process of digitalization opens up a new field for technology assessment (TA) in an interconnected world of shared responsibilities. TA stems from technology-driven problems in the Western hemisphere, particularly in the US in the 1960s. In this context, TA was a question of political regulation and engineering ethics. Technology as an area for experts and/ or industrial technologies was complemented by a new kind of personalized technology, which was simultaneously established by new super companies and individual users. With the emergence of the public usage of information- and communications technology (ICT) in the 1990s, new aspects of TA came to the fore: individual responsibilities, supranational regulations, intercultural values, and at the same time global efforts to use tech- 
nologies for a better society. In response to the transformation in human-machine interaction, ICT calls for underlining the relevance of new forms of governance and participation in TA.

Against the backdrop of widespread optimism, this TATuP special topic addresses less regarded aspects of digitalization in the Global South ${ }^{1}$. These neglected aspects include neo-colonialism, barriers to access, (digital) illiteracy, and the gender digital divide. They all relate to unequal power relations between the Global North and South and between different stakeholders in society, as well as existing socioeconomic, gender, and ethnic relations. They engender inequalities such as global digital divides (see Wakunuma in this TATuP special topic), and, in the context of digitalization and the project of a global information society, they provoke ethical questions about global justice and equality.

The present article exemplarily provides an overview of the status quo of digitalization in Africa while simultaneously addressing the following issues, which are dealt with in detail in the individual articles of this special topic:

(i) Neo-colonialism: From a postcolonial perspective, digitalization processes in the Global South are a cause for concern as the dominance of foreign players and foreign ICT and therefore foreign values, perspectives, and ideas - resembles colonial structures (see Holdermann and Aal in this TATuP special topic).

(ii) General barriers to access: Barriers include strong regional differences in internet and ICT adoption rates, high costs of internet (e.g. mobile data), existing social inequalities which may reinforce or exacerbate access barriers, and government-facilitated internet shutdowns. Moreover, (digital) skills, language, and gender can constitute barriers, but also social hierarchies that prevent people from benefitting from access (see Keja and Knodel in this TATuP special topic).

(iii) (Digital) illiteracy and language barriers: Skills such as (digital) literacy and (English) language skills are crucial to facilitate or even enable access to ICT in the first place. With illiteracy and language barriers persisting among some societal groups, ICT cannot be used as intended. However, people are slowly appropriating ICT and developing strategies to benefit from them (see Sègla in "Images and voices from digital Africa" in this TATuP special topic).

(iv) Gender digital divide: Social, economic, and political barriers often impede women's access to ICT. Women generally have lower ICT literacy rates, less ownership of devices, and therefore less access ${ }^{2}$. This is a global phenomenon,

1 Thereby, it is inspired by the stimulating debates that took place at the conference "Digitalization in Africa: Interdisciplinary perspectives on technology, development, and justice" in Tübingen, Germany, in September 2018. 2 It is important to note that not all women are disadvantaged or equally affected by the so-called gender digital divide, and that not all men have more access than all women. This paper does not intend to essentialize. However, space constraints mean it can unfortunately merely address "women" rather than a variety of gender identities. seen in for instance Latin America as much as in Africa (see Martinez Demarco in this TATuP special topic).

In regarding these issues, this TATuP special topic discusses important but largely neglected ethical aspects of digitalization. On the one hand, ethical perspectives are crucial to evaluate digitalization processes in terms of justice and to provide concepts for an inclusive and fair development of the African and international information society in the future. On the other hand, it is vital to consider counter narratives as sources of empowerment; for instance, values and traditions in Africa and elsewhere may serve as a source of success in digital transformation and allow for digitalization "out of Africa" (see Rademacher and Grant in this TATuP special topic).

\section{Actors and power relations in Africa's digitalization process}

Politics and power relations arguably lie at the core of Africa's digitalization process. Involved stakeholders include national governments, inter-governmental bodies such as the African Internet Governance Forum, as well as foreign governments; transnational corporations like Alphabet, Alibaba, Tecno Mobile, or the German IT company SAP; but also start-ups and tech hubs; civil society organizations, activists, journalists, and, of course, users.

National governments are important key drivers of digitalization on the African continent. Due to their engagement, digital service provision has increased over the past years and the mobile economy has created numerous new jobs. Yet, African governments' digitalization agendas remain vague in terms of goals and steps to be taken. Additionally, many governments engage

\section{The worldwide process of digi- talization opens up a new field for technology assessment in an interconnected world of shared responsibilities.}

in abusive practices to control the flow of information, particularly on social media. Thereby, governments strategically use internet shutdowns, mostly around the time of elections or during protests (Majama 2018).

At the international level, political and economic power relations pervade negotiations on internet governance, for instance in the area of e-commerce. Online trade and shopping have been met by massive demand in Africa, and African governments 
have embraced this trend. Yet, when it comes to international negotiations on e-commerce (e.g. at the World Trade Organization - WTO), African governments' performance and position vis-à-vis the USA and China are weak (Kiiza 2018), which might be due to their high indebtedness and the organizational character of global actors such as the World Bank or the WTO.

Global tech giants such as Facebook, Microsoft, Huawei or Alibaba also embody unequal power relations within Africa's digitalization process. Thereby, their role is ambiguous: On the one hand, transnational corporations empower local people by providing much-needed economic opportunities in the form of ing the digital divide (Wakunuma 2018; Masika and Wakunuma 2017; Kelbessa 2018). Moreover, concerns regarding autonomy and freedom of expression arise with regard to China's heavy investment in African digitalization: China as an authoritarian regime has few inhibitions to align with authoritarian African governments and provide technology for repressive practices (Majama 2018; Wakunuma 2018). Overall, the fact that political regimes can be embedded in technology for development in the Global South adds another important layer to recent debates in TA over the relation between technology, TA, and democracy (Grunwald 2018).

\section{The paradigm of progress has been central to modernization theory and has promoted the export of Western interpretations of certain values through value-laden technology.}

ICT-based jobs (Busch 2018). On the other hand, exploitation and precarious work conditions are prevalent in the digital economy - for instance the dumping of foreign e-waste in African countries or the employment of women in the low-wage and lowskill ICT sector (Kelbessa 2018; Gillard et al. 2008). Moreover, transnational tech giants have been accused of so-called digital colonialism. This is one of the four above-mentioned aspects of digitalization processes in the Global South that we will now assess in more detail.

\section{Digital colonialism}

Concerns about digital colonialism are caused by increasing ICT exports, in particular from Western countries and China to Africa (Wakunuma 2018). Among the most used ICT systems in Africa today are those produced by Huawei (China), Tecno Mobile (China), Motorola (USA), Infinix (Hong Kong), and Samsung (South Korea). These companies have realized the potential of African markets and started catering to the needs of Africans, e.g. by creating longer-life batteries that answer to the problem of scarce power supplies in many African regions (Majama 2018). However, by exporting their products to a vastly different cultural context, transnational corporations are also imposing their values (embedded in the design of their technologies) on African people.

Specifically, technology production, promotion, and export are based on the idea that progress through technology is vital for the advancement of societies. This paradigm has been central to modernization theory and has promoted the export of Western interpretations of certain values through value-laden technology (Heesen 2004). Such technology centered conceptions of progress and development may conflict with local conceptions, e. g. in the case of privacy (see below). Besides, exported Western or Chinese technology may be based on discriminating algorithms and incorporate gender biases, further deepen-
Several dangers for African ICT users thus result from exported technology, fostered by unequal power relations. These include value impositions, the potential abuse of private data, and surveillance. Besides, new (technological) dependencies may be created (Wakunuma 2018; Kelbessa 2018). Often, development projects from the Global North link their financial support to so-called good governance, and good governance to e-governance. This situation can reinforce the overall dependency of countries in the Global South, since software and hardware systems become crucial to functioning public sectors. However, these systems have been introduced by the USA or China and cannot necessarily be maintained by key actors in countries of the Global South (Wade 2002).

\section{General barriers to access}

Other challenges of digitalization include limited or no access to ICT devices and services, the high cost of airtime or data, and weak ICT infrastructure. Even though "the digital face of Africa is mobile" ( 82 percent of the African population had a mobile connection in 2018), only a portion (34 percent) of the population had access to the internet in 2018. While mobile phones are prevalent, bandwidth is scarce and the cost of internet access constitutes a significant percentage of a user's income (Majama 2018; Kemp 2018). Despite much activity in the field of digitalization, in reality most Africans have no access to the internet. Infrastructure and affordability remain important issues on Africa's digitalization agenda.

While these issues are arguably mainly economic, government shutdowns and associated repressive policies (e.g. after the 2016/17 elections in Uganda) constitute notable political barriers to people's access to information and ICT. Beyond the fact that journalists, activists, and human rights advocates are particularly negatively affected by these crackdowns on free speech, these so-called blackouts also impede areas such as healthcare 
provision, and have massive economic impacts, compromising the promise of economic prosperity through digitalization. Increasingly, civil society actors are now seeking legal remedy by contesting shutdowns in national courts, e.g. in Uganda, where the shutdown of 2016 (social media such as Facebook or Twitter were blocked during the elections) are still reviewed by the high court in Kampala (Dahir 2018).

\section{(Digital) illiteracy and language barriers}

Even when general barriers to access are overcome, users may lack the skills to benefit from ICT: Illiteracy persists in many African societal groups, and the illiterate cannot use most ICT systems as intended. Moreover, language barriers remain a major challenge, as exported technology is often not available in local languages (see Sègla in "Images and voices from digital Africa" in this special topic). Lastly, users may lack skills such as basic electronic data processing knowledge or information literacy skills needed to independently use ICT (Toffa 2018).

At the local level, people are working around these issues by appropriating ICT to suit their needs and preferences. By way of example, indigenous people such as the Yoruba in West Africa struggle with the use of ICT services such as SMS and online platforms (whether e-government or social media), which rely on alphabetic literacy and are often designed in a foreign language. The mostly illiterate Yoruba people of Benin have thus developed strategies to nonetheless benefit from ICT such as using signs and specific symbols or voice messages on WhatsApp (see Sègla in "Images and voices from digital Africa" in this TATuP special topic).

This example shows that basic ICT skills are crucial. Small steps matter, whether it is learning to create a blog entry or exploring all functions of one's phone (Toffa 2018). This is especially true for marginalized members of society.
Another barrier to women's information access is gendered violence online such as doxing, stalking, bullying, and even revenge pornography (Segrave and Vitis 2017). Violence may also extend into the private sphere, with a husband controlling his wife's mobile phone due to a fear of her flirting online. Finally, women have been found to lack confidence when it comes to ICT use and the "technology-is-not-for-me-syndrome" is prevalent among women (Wakunuma 2018). Improving women's digital skills is one solution that can contribute to reducing the cycle of poverty and preparing women for the future of work (Toffa 2018). ICT training for women and girls potentially leads to new competences and leverages female empowerment, eventually resulting in a transformation of established power relations (Ramey and Brzezinski 2018). On the other hand, there is the danger of discriminating against gender non-conforming people by providing ICT training only for women (see Martinez Demarco in this TATuP special topic).

\section{Ethical questions of digitalization in Africa}

The discussion above demonstrates that, while much has been done to advance digitalization in Africa, inequalities and divides in ICT access persist between the Global South and North, men and women, rural and urban areas, and the generations. Power relations within the process of digitalization are asymmetric, and transnational corporations, foreign governments, and national repressive policies shape Africa's digitalization.

This is striking, given the widespread optimism that connecting different world regions would automatically lead to prosperity, democracy, and more global equality. Even though the internet was at first available only to elites, the idea was that, over

\section{The gender digital divide refers to social, economic, and political inequalities between men and women with regard to ICT access and use.}

\section{Gender digital divide}

The gender digital divide refers to inequalities with regard to ICT access and use between men and women. Social, economic, and political barriers hinder many women's access to ICT. Women have lower ICT literacy rates, less ownership of devices, and therefore less access (Chakravorti 2017; ITU 2017). Patriarchal structures and cultural practices of both male and female authorities impede access, because they consider internet content inappropriate for wives and daughters. Moreover, there is concern that women may neglect their household and family responsibilities, which are ascribed to them due to the prevalence of gender roles (Majama 2018). time, everyone would eventually enjoy the benefits of digital life. Moreover, it was believed that ICT would have a democratizing effect similar to a Habermasian ideal speech situation: If everyone had the opportunity to voice their opinion, democracy would flourish (Ess 2018).

Ethicists have pointed out that this technological determinism does not hold true in light of the American and Chinese domination of global digitalization processes and the replication of social structures of inequality in the digital sphere (Ess 2018). Kelbessa (2018) calls for the establishment of codes of ethics and responsibilities to be followed when developing and introducing new technologies. Sustainable development, partici- 
pation and self-determination should be at the core of technological innovation. Ethical concerns about digitalization in Africa include (1) the fear of digital colonialism through value-laden technology, (2) the violation of privacy and its implications for societies and individual identities, and (3) the exclusion of marginalized populations as well as the neglect of environmental protection (Schelenz and Schopp 2018).

Addressing concern (1), philosophers of technology argue that technology is not neutral but has certain values embedded in it. These values reflect the norms and standards of the society where the technology was developed (Simon 2016). In the African context, the above-mentioned implementation of foreign

\section{Ethical concerns about digitalization in Africa include the fear of digital colonialism through value-laden technology.}

values (especially through technology as a symbol of modernization and progress) is particularly delicate, as it resembles and potentially replicates the imposition of European norms during colonial times. While African countries have struggled to decolonize and end European control, digitalization may now pave the way for new forms of "digital colonialism" (Wakunuma 2018; Ess 2009). Thereby, foreign values may be imposed on African societies through "computer-mediated cultural imperialism" (Ess 2009, p. 116). One example is Facebook's application "Free Basics". The App includes Facebook, BBC, some pages of Wikipedia, and other sites such as job portals or maternal health information. "Free Basics" has been criticized for providing only certain content and violating principles of net neutrality, displaying mostly Western content and ignoring popular national or local websites, prioritizing English over local languages, not responding to the needs of users, and collecting large amounts of data (Global Voices 2017).

Digitalization through value-laden technology is further complicated by the fact that different societies might have different interpretations of the same value. One example is privacy, which is usually understood as individual privacy in North America and Europe. However, African and Asian societies see privacy as related to the community. When regarding digitalization in the Global South, scientists and practitioners must therefore consider notions of privacy, e. g. by engaging with the philosophy of Ubuntu, and how they conflict with Western privacy concepts embedded in ICT. Intercultural information ethics deals with exactly such ethical questions, aiming at integrating diverse cultural perspectives (Ess 2009, 2018).
With regard to concern (2), ethicists are worried about the lack of data protection in the context of digitalization in Africa. This is a particularly sensitive topic, as human rights violations remain frequent in many countries. ICT-based projects such as the documentation of human rights violations in Kenya on the Ushahidi platform are thus necessary to raise awareness and hold violators accountable (Kelbessa 2018). When privacy and data of computer scientists developing such platforms and of journalists providing information about abuses is endangered, openness, justice and democracy are at stake. Moreover, another concern regarding data protection in the African context is the widespread lack of digital literacy, including knowledge on how to protect one's data from unwanted privacy intrusions.

Concerning (3), ethicists address the exclusion of marginalized populations through language and technology design, which does not take into account end users' perspectives in the development of devices, apps, and ICT literacy programs (Heeks 2008). Finally, environmentalists see environmental ethics being violated through digitalization in Africa, for example through the exportation of e-waste to African countries, which has seriously negative effects on marginalized populations and the environment (Kelbessa 2018).

The frequently neglected ethical concerns raised in this paper and the potential ethical responses point towards new questions central to all fields of study and practice engaging in and reflecting upon global digitalization: What does an equal and fair global digital society look like? And how can we put that into practice?

\section{Acknowledgements}

This TATUP special topic builds on and is inspired by the stimulating debates that took place at the conference "Digitalization in Africa: Interdisciplinary Perspectives on Technology, Development, and Justice" at the International Center for Ethics in the Sciences and Humanities, University of Tübingen, from 26 to 27 September 2018. Our thanks go to all the speakers of the conference. Their expertise and insights have informed this introductory article.

cited conference papers

Bush, Ulrich (2018): Building a digital business in Ghana. The challenges to overcome, the opportunities beyond.

Ess, Charles (2018): Culture, digitalization, and the digital divide. Existential and virtue ethics approaches. A (long) view from the (far) North. Kelbessa, Workineh (2018): Digitalization in Africa. Opportunities and challenges for human rights and development.

Kiiza, Africa (2018): A Trojan horse? E-commerce and its potential risks for Africa.

Majama, Koliwe (2018): Exploring Africa's digitalization agenda in the context of promoting civil liberties.

Toffa, Florence (2018): Building a digitally skilled generation for sustainable, impactful development in Africa.

Wakunuma, Kutoma (2018): Critical questions at the intersection of digitalization, development, and justice. 


\section{References}

Chakravorti, Bhaskar (2017): There's a gender gap in internet usage. Closing it would open up opportunities for everyone. Accessible online https://hbr.org/2017/12/theres-a-gender-gap-in-internet-usageclosing-it-would-open-up-opportunities-for-everyone, last accessed on 28. 05.2019.

Dahir, Abdi (2018): A court case in Uganda could have implications for future internet shutdowns in Africa. Accessible online https://qz.com/ africa/1458287/uganda-court-to-review-2016-election-internet-shutdowns, last accessed on 03.06.2019.

Ess, Charles (2009): Digital media ethics. Cambridge, MA: Polity Press.

Gillard, Hazel et al. (2008): "Missing Women". Gender, ICTs, and the shaping of the global economy. In: Information technology for development 14 (4), pp. 262-279.

Global Voices (2017): Free basics in real life. Six case studies on Facebook's internet "On Ramp" initiative from Africa, Asia, and Latin America. Accessible online https://advox.globalvoices.org/wp-content/uploads/2017/08/ FreeBasicsinRealLife_FINALJuly27.pdf, last accessed on 28. 05.2019.

Grunwald, Armin (2018): Technikfolgenabschätzung und Demokratie. Notwendige oder kontingente Verbindung? In: TATuP - Zeitschrift für Technikfolgenabschätzung in Theorie und Praxis 27 (1), pp. 40-45.

Heeks, Richard (2008): ICT4D 2.0. The next phase of applying ICT for international development. In: Computer 41 (6), pp. 26-33.

Heesen, Jessica (2004): Technik als Mission. Wie Vereinte Nationen und G8 die digitale Spaltung überwinden wollen. In: Rupert Scheule, Rafael Capurro and Thomas Hasumanninger (ed.): Vernetzt gespalten. Der Digital Divide in ethischer Perspektive. München: Fink, pp. 213-224.

ITU - International Telecommunication Union (2017): ICT facts and figures 2017. Accessible online https://www.itu.int/en/ITU-D/Statistics/Documents/facts/ ICTFactsFigures2017.pdf, last accessed on 28. 05.2019.

Kemp, Simon (2018): Digital in 2018. Essential insights into internet, social media, mobile, and e-commerce use around the world. We are social and hootsuite. Accessible online https://wearesocial.com/blog/2018/01/global-digitalreport-2018, last accessed on 16.05.2019.

Majama, Koliwe (2018): Exploring Africa's digitalisation agenda in the context of promoting civil liberties. Interdisciplinary perspectives on technology, development, and justice. Tübingen, Germany, 26.-27. 09. 2018. Accessible online: https://timms.uni-tuebingen.de/tp/UT_20180926_001_daethics2018_0001, last accessed on 28. 05.2019.

Masika, Rachel; Kutoma Wakunuma (2017): Cloud computing, capabilities and intercultural ethics. Implications for Africa. In: Telecommunications Policy 41 (7-8), pp.695-707.

Ramey, Virginie; Brzezinski, Bartosz (2018): Miss geek Africa. Women and girls in digitalisation. Accessible online https://europa.eu/capacity4dev/ articles/miss-geek-africa-women-and-girls-digitalisation, last accessed on 16.05.2019.

Segrave, Marie; Vitis, Laura (2017): Gender, technology and violence. New York: Routledge.

Schelenz, Laura; Schopp, Kerstin (2018): Digitalization in Africa. Interdisciplinary perspectives on technology, development, and justice. In: International Journal of Digital Society 9 (4), pp. 1412-1420.

Simon, Judith (2016): Values in design. In: Jessica Heesen (ed.) (2016): Handbuch Medien und Informationsethik. Stuttgart: J. B. Metzler, pp. 357-364.
Wade, Robert Hunter (2002): Bridging the digital divide. New route to development or new form of dependency. In: Global Governance 8, pp. 443-466.

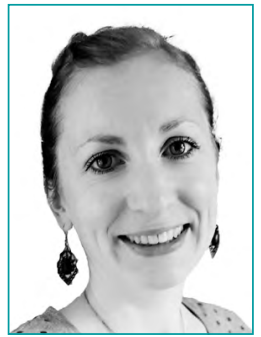

\section{KERSTIN SCHOPP}

studied Biology and Culture \& Society of Africa with a focus on Development Sociology and African History in Karlsruhe and Bayreuth with a research stay in Cameroon. Since 2016, Kerstin works at the International Center for Ethics in the Sciences and Humanities. Her research interests are socioecological consequences of human interventions in nature and society, sustainable development, the equestrian statue in Windhoek, Namibia, and (neo)colonialism(s).

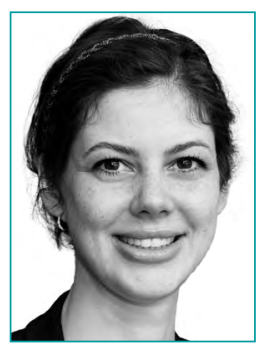

\section{LAURA SCHELENZ}

studied American Studies and Peace and Conflict Research in Heidelberg and Frankfurt with stays in the USA and Hungary. She was a conflict researcher for four years and worked with human rights organizations in Germany. Since September 2017, Laura works as a researcher at the International Center for Ethics in the Sciences and Humanities and engages primarily with questions of ethics, technology, gender, and development.

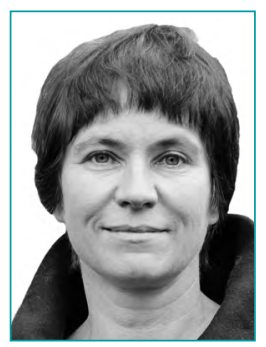

\section{PD DR. JESSICA HEESEN}

is head of the research focus "Media Ethics and Information Technology" at the International Center for Ethics in the Sciences and Humanities at the University of Tübingen. Jessica's research focusses are Social Philosophy and Philosophy of Technology, Ethics, Information Ethics, Media Ethics, and Security Ethics.

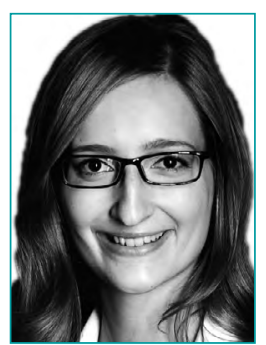

\section{MARIA PAWELEC}

studied Politics and Public Administration and Contemporary European Studies in Konstanz, Istanbul, Bath and Berlin. She then worked for the Robert Bosch Foundation on projects to promote European cohesion, close relations with the EU's neighbouring countries, and good governance. In 2016, Maria joined the International Center for Ethics in the Sciences and Humanities. Her research interests include digitalization, development and democratization, migration, populism, and EU foreign policy. 